\title{
Observing calving-generated ocean waves with coastal broadband seismometers, Jakobshavn Isbræ, Greenland
}

\author{
Jason M. AMUNDSON, ${ }^{1}$, John F. CLINTON, ${ }^{2}$ Mark FAHNESTOCK, ${ }^{3}$ Martin TRUFFER, ${ }^{4}$ \\ Martin P. LÜTHI, ${ }^{5}$ Roman J. MOTYKA ${ }^{4}$ \\ ${ }^{1}$ Department of Geophysical Sciences, University of Chicago, Chicago, IL, USA \\ E-mail: jason.amundson@uas.alaska.edu \\ ${ }^{2}$ Swiss Seismological Service (SED), ETH Zürich, Zürich, Switzerland \\ ${ }^{3}$ Institute for the Study of Earth, Oceans and Space, University of New Hampshire, Durham, NH, USA \\ ${ }^{4}$ Geophysical Institute, University of Alaska, Fairbanks, AK, USA \\ ${ }^{5}$ Laboratory of Hydraulics, Hydrology and Glaciology (VAW), ETH Zürich, Zürich, Switzerland
}

\begin{abstract}
We use time-lapse photography, MODIS satellite imagery, ocean wave measurements and regional broadband seismic data to demonstrate that icebergs that calve from Jakobshavn Isbræ, Greenland, can generate ocean waves that are detectable over $150 \mathrm{~km}$ from their source. The waves, which are recorded seismically, have distinct spectral peaks, are not dispersive and persist for several hours. On the basis of these observations, we suggest that calving events at Jakobshavn Isbræ can stimulate seiches, or basin eigenmodes, in both Ilulissat Icefjord and Disko Bay. Our observations furthermore indicate that coastal, land-based seismometers located near calving termini (e.g. as part of the new Greenland Ice Sheet Monitoring Network (GLISN)) can aid investigations into the largely unexplored, oceanographic consequences of iceberg calving.
\end{abstract}

\section{INTRODUCTION}

Calving icebergs generate large, locally destructive ocean waves. These waves may (1) promote subsequent calving by causing ice fatigue through repeated flexure (MacAyeal and others, 2009), (2) agitate and fragment icebergs and sea ice, leading to a weakening of proglacial ice coverage (Amundson and others, 2010), and (3) generate turbulence when breaking on shallow, sloping shorelines. Additionally, measurements of wave energy can be used to monitor calving (Nettles and others, 2008) and to aid studies of icebergcalving energetics and its consequences, such as turbulence generated in the wake of capsizing icebergs (Burton and others, 2012). However, difficulties in instrumenting proglacial fjords with pressure gauges have hampered efforts to quantitatively describe and assess the importance of calvinggenerated waves. Previous work by MacAyeal and others (2009) demonstrated that short-period ( 10-50s) calvinggenerated ocean waves can be recorded with seismometers deployed on ice shelves and tabular icebergs (which respond to ocean swell). Such measurements, although highly useful for understanding the oceanic response to calving events, are not possible in regions that do not have large ice shelves (e.g. most of Greenland). Here we show that by responding to induced ground tilt, coastal broadband seismometers can be used to detect and investigate much longer-period (>100s) calving-generated waves.

We focus our study on Jakobshavn Isbræ, Greenland (Fig. 1), a fast-flowing outlet glacier that drains $>5 \%$ of the Greenland ice sheet (Rignot and Kanagaratnam, 2006). The glacier discharges into $55 \mathrm{~km}$ long Ilulissat Icefjord, which connects to Disko Bay by the town of Ilulissat. In the late 1990s the glacier began a rapid calving retreat (Thomas and others, 2003; Joughin and others, 2004; Luckman and Murray, 2005) that resulted in the loss of an extensive floating

* Present address: University of Alaska Southeast, Juneau, AK, USA. tongue (Csatho and others, 2008). Prior to and during the break-up of the floating tongue, the glacier frequently calved tabular icebergs with horizontal dimensions of 2-3 km (Stove and others, 1983; Birnie and Williams, 1985). Tabular icebergs are now rare, with the dominant style of calving consisting of the detachment and immediate capsize of full-glacier-thickness icebergs (with volumes $0.1-0.25 \mathrm{~km}^{3}$ ). Because these icebergs capsize, they release tremendous amounts of gravitational potential energy into the fjord ( $\sim 10^{14}$ J; Amundson and others, 2008; MacAyeal and others, 2011). This style of calving, although less common at the time, also occurred prior to the break-up of the floating tongue (Epprecht, 1987).

This paper consists of two distinct but complementary parts. First, we use field data from 2007-08 to develop an algorithm for detecting large, multiple-iceberg calving events using regional seismic data and MODIS (Moderate Resolution Imaging Spectroradiometer) satellite imagery. This algorithm allows us to explore seismic data collected around Disko Bay prior to our recent field campaigns. Second, we use time-lapse photography, ocean wave measurements and seismic data (both recent and older data) to show that icebergs that calve from Jakobshavn Isbræ can generate long-period ocean waves that are seismically recorded throughout Disko Bay at distances up to $150 \mathrm{~km}$ from the glacier terminus.

\section{INSTRUMENTATION}

We have documented the dynamics of Jakobshavn Isbræ's terminus and proglacial fjord (Fig. 1) since 2007 with timelapse cameras, tide gauges and local seismic stations JAKO (17 May 2007 to 3 August 2008) and WIND (16 August 2009 to present). Details of the field measurements are presented by Amundson and others $(2008,2010)$. Note that the sample interval of the tide gauge in Ilulissat Harbor, normally 20 min, 


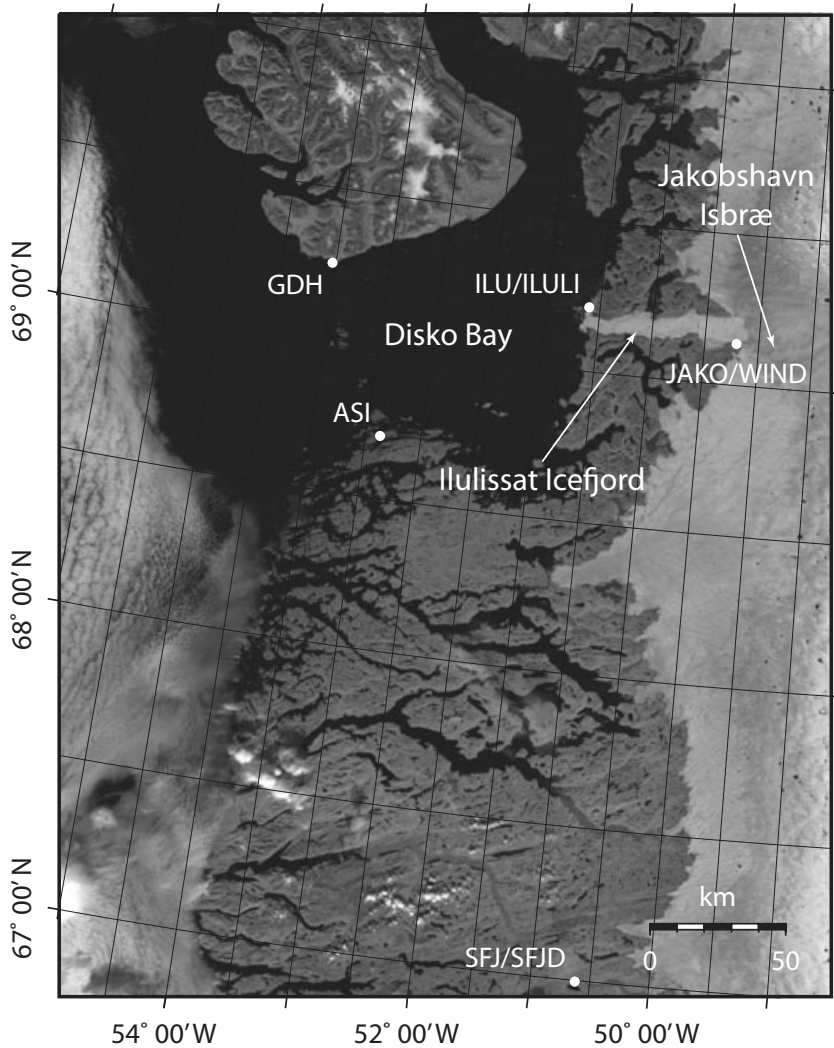

Fig. 1. MODIS image of the study area from 9 August 2008. Seismic stations are indicated by white dots. Station SUMG is $600 \mathrm{~km}$ northeast of station ILU/ILULI. We have operated a tide gauge in Ilulissat Harbor (near station ILU/ILULI) and time-lapse cameras (near station JAKO/WIND) since 2007.

was changed to 1 min from 12 to 29 August 2009, in order to better characterize calving-generated ocean waves.

In addition, we have acquired near-daily MODIS satellite imagery and regional broadband seismic data dating back to the late 1990s. Our seismic database includes stations GDH (25 May 2000 to 19 March 2001), ASI (10 May 2004 to 12 May 2006), ILU (13 May 2004 to 31 August 2005), SFJ/SFJD (21 March 1995 to present), SUMG (14 May 2003 to present) and ILULI (6 August 2009 to present). We converted the seismic data from raw counts to velocity but did not correct for frequency response. The instrument locations are shown in Figure 1. Station SUMG (not shown) is located at Summit Camp and is the only station in our database that is located on the ice sheet. Data from all of these stations have been incorporated into the new Greenland Ice Sheet Monitoring Network (GLISN; http://glisn.info).

\section{SEISMIC DETECTION OF CALVING EVENTS}

Calving events that currently occur at Jakobshavn Isbræ can be identified in regional seismic data by their unique seismic characteristics: (1) emergent, cigar-shaped envelopes that last 20-120 min, (2) a lack of distinct P- or S-wave arrivals, (3) one to several peaks in amplitude that coincide with the calving and immediate capsize of individual icebergs and (4) maximum energy in the $2-5 \mathrm{~Hz}$ band (Amundson and others, 2008, 2010). These characteristics are often visible in seismic data recorded $600 \mathrm{~km}$ from the terminus (at station SUMG), but only after filtering with a $2-5 \mathrm{~Hz}$ bandpass filter (Fig. 2). We emphasize that these characteristics are


Fig. 2. Seismic signals (vertical seismometer channels) generated by a calving event at Jakobshavn Isbræ on 21 August 2009. The data were filtered with a $2-5 \mathrm{~Hz}$ bandpass filter. See figure 1 for seismometer locations.

associated with icebergs that capsize as they calve into the ocean; seismic observations of calving events that produce (exclusively) tabular icebergs are lacking.

When coupled with near-daily MODIS imagery, the calving events can be confidently detected with just a single seismometer located within a few hundred kilometers of the terminus. To demonstrate, we visually browsed data from station SFJ/SFJD (Fig. 1) that were collected between May 2007 and August 2008, a time period in which our field observations provide accurate timing of calving events (Table 1). In addition to searching for seismic signals with the characteristics of calving events described above, we also required that (1) the peak amplitude in the $2-5 \mathrm{~Hz}$ band exceeded the background noise by at least a factor of four (it was often close to 10 or 20) (Fig. 3), (2) there were two or more amplitude peaks, which biased our selections toward especially large, multiple-iceberg calving events but also removed any local tectonic signals and (3) any energy in the surface wave band (35-150 s period) had to be consistent with a regional source (i.e. with very little dispersion) and have peak amplitudes exceeding the background noise by a factor of ten or less. Surface waves arriving from distant, tectonic earthquakes are generally highly dispersed and can have signal-to-noise ratios that are orders of magnitude higher. The majority of the seismic signals with these characteristics should originate from the main (southern) branch of Jakobshavn Isbræ, which is more productive than the glacier's northern branch and which calves considerably larger icebergs than all other glaciers within at least $350 \mathrm{~km}$ of SFJ/SFJD. Finally, candidate events were verified with MODIS imagery by looking for periods of terminus retreat and/or rapid advection of the proglacial ice melange (Amundson and others, 2010). Although MODIS 
Table 1. List of calving events that occurred during a time period in which a seismometer and time-lapse cameras near the glacier's terminus ran nearly continuously. Onset times (in UTC), were determined from these local observations. Events through 10 May 2008 are taken from Amundson and others (2008)

\begin{tabular}{|c|c|c|c|}
\hline Date & hh:mm:ss & Date & hh:mm:ss \\
\hline 16 May 2007 & $19: 29: 31^{*}$ & 28 May 2008 & $20: 01: 35^{*}$ \\
\hline 18 May 2007 & $09: 51: 40^{* \dagger}$ & 4 Jun 2008 & $00: 40: 11^{*}$ \\
\hline 21 May 2007 & $16: 32: 36^{*}$ & 6 Jun 2008 & 11:36:10 \\
\hline 29 May 2007 & $14: 04: 32^{*}$ & 6 Jun 2008 & $13: 58: 29^{*}$ \\
\hline 5 Jun 2007 & $09: 11: 07^{*}$ & 11 Jun 2008 & 05:19:39* \\
\hline 5 Jun 2007 & $13: 07: 42 *$ & 12 Jun 2008 & $00: 50: 16$ \\
\hline 5 Jun 2007 & $14: 07: 44^{*}$ & 12 Jun 2008 & $17: 08: 15^{*}$ \\
\hline 20 Jun 2007 & 05:30:00* & 12 Jun 2008 & $20: 13: 12^{*}$ \\
\hline 27 Jun 2007 & 15:05:04* & 13 Jun 2008 & 21:55:11* \\
\hline 29 Jun 2007 & $05: 49: 30^{*}$ & 14 Jun 2008 & 11:58:07 \\
\hline 30 Jun 2007 & 10:41:48 & 15 Jun 2008 & 10:50:06 \\
\hline 3 Jul 2007 & $20: 37: 48$ & 15 Jun 2008 & $21: 07: 27$ \\
\hline 4 Jul 2007 & $06: 46: 54$ & 16 Jun 2008 & $01: 33: 27^{*}$ \\
\hline 4 Jul 2007 & $16: 43: 35^{*}$ & 17 Jun 2008 & $13: 45: 53^{*}$ \\
\hline 10 Jul 2007 & 07:52:00* & 18 Jun 2008 & $04: 13: 24$ \\
\hline 14 Jul 2007 & 07:38:05* & 22 Jun 2008 & $04: 54: 19^{*}$ \\
\hline 16 Jul 2007 & 10:34:05 & 25 Jun 2008 & $02: 16: 48^{*}$ \\
\hline 16 Jul 2007 & $15: 21: 43$ & 30 Jun 2008 & 02:02:05* \\
\hline 17 Jul 2007 & $15: 29: 47$ & 30 Jun 2008 & $03: 35: 32$ \\
\hline 26 Jul 2007 & $18: 22: 02^{*}$ & 1 Jul 2008 & $20: 44: 48$ \\
\hline 30 Jul 2007 & $11: 25: 22^{*}$ & 2 Jul 2008 & 00:01:11 \\
\hline 30 Jul 2007 & 18:49:29 & 2 Jul 2008 & 01:39:26* \\
\hline 1 Aug 2007 & 19:51:43* & 2 Jul 2008 & $12: 56: 33$ \\
\hline 2 Aug 2007 & $13: 31: 31^{*}$ & $6 \mathrm{Jul} 2008$ & $00: 57: 29$ \\
\hline 2 Aug 2007 & 19:02:54* & $10 \mathrm{Jul} 2008$ & $12: 31: 52$ \\
\hline 4 Aug 2007 & $07: 47: 55^{* \ddagger}$ & 13 Jul 2008 & $04: 47: 46^{*}$ \\
\hline 17 Aug 2007 & $12: 01: 43$ & 14 Jul 2008 & 03:50:52 \\
\hline 20 Aug 2007 & $22: 19: 20 * \ddagger$ & 14 Jul 2008 & 04:33:36* \\
\hline 19 Sep 2007 & $06: 16: 56^{*}$ & 15 Jul 2008 & $08: 17: 19^{*}$ \\
\hline 17 Oct 2007 & 08:49:01* & $16 \mathrm{Jul} 2008$ & $10: 30: 44^{*}$ \\
\hline 19 Apr 2008 & 15:39:48* & 16 Jul 2008 & $12: 21: 38^{*}$ \\
\hline 26 Apr 2008 & 11:58:01* & $17 \mathrm{Jul} 2008$ & $01: 51: 14$ \\
\hline 3 May 2008 & 09:49:00* & 18 Jul 2008 & 18:59:58 \\
\hline 10 May 2008 & $21: 00: 12^{*}$ & 19 Jul 2008 & $10: 44: 40^{*}$ \\
\hline 11 May 2008 & 03:28:38* & $24 \mathrm{Jul} 2008$ & $02: 32: 26^{*}$ \\
\hline 14 May 2008 & 00:10:39 & 28 Jul 2008 & 07:10:45 \\
\hline 21 May 2008 & 10:17:59* & & \\
\hline
\end{tabular}

*ndependently detected with station SFJD.

I Iceberg capsized in the middle of the fjord; not a calving event.

${ }^{\ddagger}$ Not previously identified by Amundson and others (2008).

imagery can be used to determine if a calving event has occurred, the pixel size $(250 \mathrm{~m})$ is too large to be useful for quantifying the size of calving events.

The calving-event detection algorithm correctly identified 47 out of 73 documented calving events; the algorithm also detected six additional events not included in Table 1. The 73 calving events include two events that were previously missed by Amundson and others (2008); one was accidentally omitted and the other was missed when the time-lapse cameras and local seismometer were temporarily turned off for data retrieval from 17 to 22 August 2007. Satellite imagery and tide-gauge data confirm that a calving event did indeed occur during this time interval.

The 26 calving events not identified by the detection algorithm are visible in the data from SFJ/SFJD and SUMG but were not selected because their far-field seismograms had only one peak in amplitude, short durations (10 min or less) and small signal-to-noise ratios. In other words, the missed
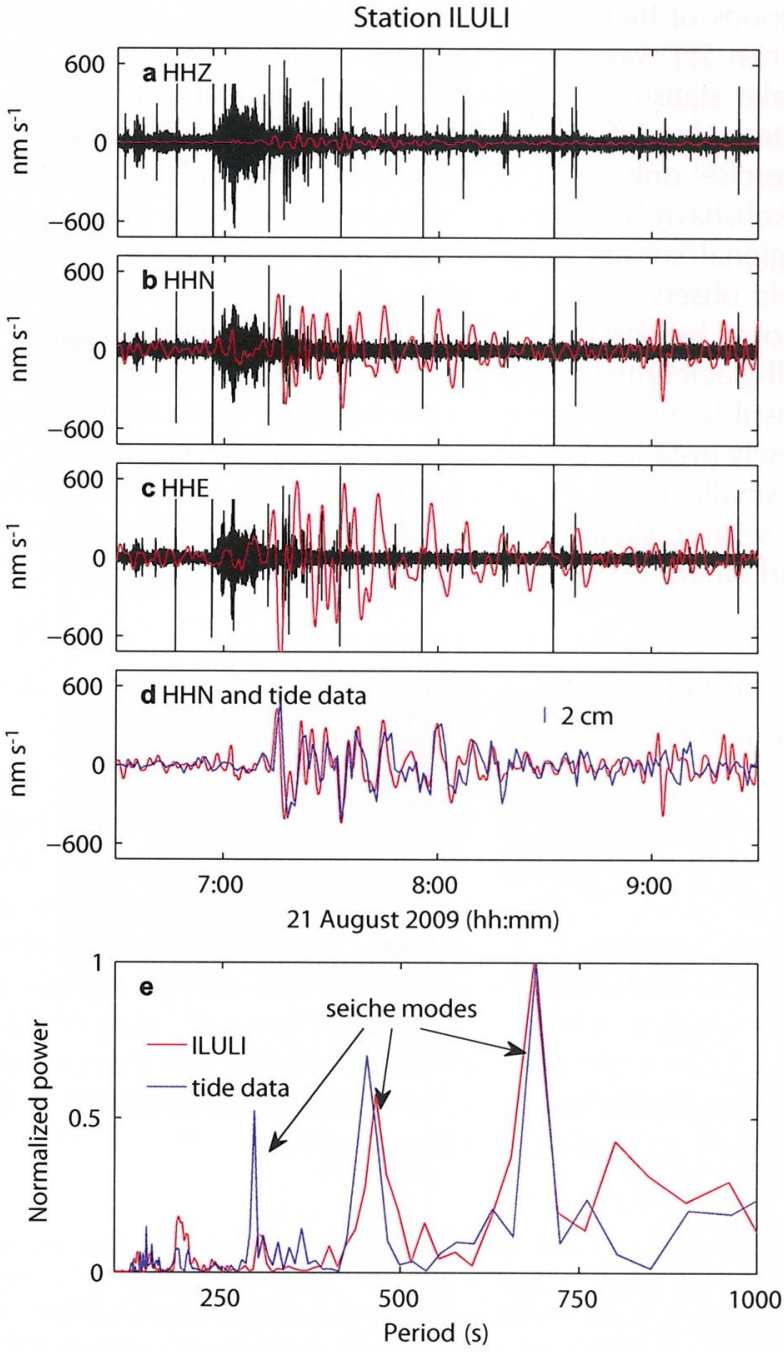

Fig. 3. Seismic data recorded at station ILULI during a calving event on 21 August 2009. (a-c) Data from the vertical (a), north (b) and east (c) channels. The data were filtered with a $2-5 \mathrm{~Hz}$ bandpass filter (black) and a 120-1200 s bandpass filter (red); the plots therefore show the velocity within each bandpass. Furthermore, we emphasize that these signals were not corrected for frequency response; the velocity in the 120-1200 s band was actually much larger than plotted. The $2-5 \mathrm{~Hz}$ energy is characteristic of all calving events (see Section 3 and Fig. 2), whereas the 120-1200 s energy appears to represent ground tilt caused by calving-generated ocean waves. (d) Comparison of the low-frequency seismic signal recorded at HHN (red; same as in (b)) with simultaneous ocean wave measurements (blue; small vertical line indicates scale). (e) Normalized power spectra of the vertical channel of station ILULI (red), corrected for instrument response, and of high-rate tide data from nearby llulissat Harbor (blue) from 06:50 to 10:50.

calving events most likely consisted of the calving of a single large iceberg

Of the six additional detections, one is known to have been caused by an iceberg capsizing in the fjord during a period of terminus quiescence, and one occurred in late December 2007, when MODIS imagery was unavailable and our cameras and local seismometer had lost power. The remaining four questionable detections were during periods when MODIS imagery was sparse and/or cloud cover obscured the terminus.

In principle, MODIS imagery and data from station SFJ/SFJD could be used to construct a calving-event catalog dating back to the late 1990s. However, large gaps and 
periods of high noise in the data, especially prior to 2005 (when SFJ was moved to a new vault and renamed SFJD), make statistical interpretation of historical calving events extremely difficult. For this reason we treat the above exercise only as a demonstration that calving events at Jakobshavn Isbræ can be confidently detected using limited, regional seismic data and MODIS imagery (i.e. no direct field observations). However, our results do indicate that it should be possible to compile a more complete catalog of full-glacier-thickness calving events at Jakobshavn Isbræ (and possibly other glaciers) in the future by using data from the newly installed GLISN seismic network. Confident detection of smaller calving events will likely require a denser network of seismic stations than is currently available (e.g. O'Neel and others, 2010).

\section{OBSERVATIONS OF LONG-PERIOD, GLACIOGENIC OCEAN WAVES}

Recent field observations indicate that long-period (>100s) ocean surface-gravity waves are recorded in Ilulissat Harbor (50 km from the glacier terminus) $\sim 10$ min after the onset of all full-glacier-thickness calving events (Amundson and others, 2008); the waves are non-dispersive and persist for several hours. Similar long-period seismic signals are concurrently recorded by nearby seismic station ILULI (Fig. 3). Several lines of evidence indicate that these seismic signals represent wave-induced ground tilt. First, we note that wave energy travels with group velocity

$$
u_{\mathrm{g}}=\frac{\partial \omega}{\partial k^{\prime}}
$$

where $\omega$ is angular frequency and $k$ is the wavenumber. The angular frequency of ocean waves is related to wavenumber, gravitational acceleration, $g$, and water depth, $h$, through the well-known dispersion relation (e.g. Gill, 1982)

$$
\omega^{2}=g k \tanh k h .
$$

In the long-wavelength limit (small $k h$ ), the group velocity is

$$
u_{g}=\sqrt{g h} .
$$

Thus, Jakobshavn Isbræ's $50 \mathrm{~km}$ long and $~ 800$ m deep fjord (Holland and others, 2008) is consistent with the observed travel time of $\sim 10 \mathrm{~min}$. Second, the long-period seismic signals are strongest in the seismometer's horizontal channels, in agreement with observations of tsunamis (including small tsunamis generated by landslides) impacting coastlines (La Rocca and others, 2004; Yuan and others, 2005; Okal, 2007) and characteristic of an inertial seismometer's response to tilting (McNamara and others, 2011). Third, and most importantly, the seismic signals closely match the shape and frequency content of the ocean waves simultaneously measured in Ilulissat Harbor (Fig. 3d-e).

Inspection of seismic data from stations ASI, GDH and ILU, which operated prior to our field campaigns, reveals that long-period seismic signals (>100 s) were also recorded at more distant stations $10-30 \mathrm{~min}$ after the onset of calving events (Fig. 4). The seismic signals lasted several hours and had distinct spectral peaks that were strongest in the horizontal channels of the seismometers. Thus these signals were also likely caused by calving-generated ocean waves.
In contrast to our recent observations at station ILULI, however, calving-generated ocean waves are only occasionally identifiable in data from ASI, ILU and GDH (Fig. 1). We have identified just nine calving-generated ocean waves in the 1031 days that the stations operated; inspection of MODIS imagery and data from SFJ/SFJD suggests that $>50$ large calving events occurred during this time. We attribute the paucity of seismically recorded, calving-generated ocean waves to the signals being obscured by periods of high seismic noise, a nonlinear coupling between ocean wave amplitude and ground tilt and/or the possibility that not all calving events radiate long-period waves into Disko Bay. In particular, stations ASI, ILU and GDH were operational at a time when the calving of tabular icebergs comprised a large percentage of the glacier's calving flux. Since tabular icebergs do not capsize as they calve into the ocean, they do not release gravitational potential energy and are therefore less likely to produce large ocean waves.

A key difference between the observations presented here and those of seismically recorded tsunamis is that tsunami wave trains (as well as other ocean swell) are dispersive and contain energy over a wide spectrum of frequencies (e.g. Munk and others, 1963; Okal, 2007). To help illustrate the difference, we have plotted the expected tsunami dispersion curves on Figure $4 \mathrm{~d}$ and $\mathrm{h}$ for the water depths presented by Holland and others (2008). These curves are generated by numerically solving Eqn (2) for $k(\omega)$ and using the result, along with Eqns (1) and (2), to compute $u_{\mathrm{g}}(\omega)$. The sharp spectral peaks, lack of dispersion and persistence of the seismic signals suggest that the waves recorded by the seismometers are seiches (Rabinovich, 2009), or basin eigenmodes, that are excited by calving events at Jakobshavn Isbræ. This hypothesis is supported by the observation that the wave frequencies typically do not vary from event to event (seiche frequency depends strongly on basin bathymetry) (Fig. 5). If these seismic signals are indeed due to seiching, then the spectral peaks seen in Figures 3 and 4 represent higher-order seiche modes, since the fundamental mode for these basins should exceed $1000 \mathrm{~s}$ (and would be undetectable seismically). The small number of spectral peaks in the data may simply be due to rapid attenuation of even higher-frequency modes.

Seiche modes depend strongly on basin bathymetry. The number of modes for a given basin is countably infinite; the actual modes that are present depend on the forcing (in this case iceberg calving). Systems of interconnected basins with variable bathymetry, like the system consisting of Disko Bay, Ilulissat Icefjord and the tributary fjords from the north and south (Fig. 1), have very complex mode structures that are difficult to predict. Using a simple, idealized bathymetry to estimate the modes of such a complex basin can yield very erroneous results (see discussion in Hutter and others, 2011, ch. 17). In addition, preliminary modeling work has shown that icebergs can affect seiche modes by introducing 'band gaps', or frequency bands that forbid wave propagation and alter the relationship between period and mode number (MacAyeal and others, 2012). Thus, since the bathymetry of Ilulissat Icefjord is known at only a few points due to the dense coverage of large icebergs in the fjord (see Holland and others, 2008), it is unlikely that a numerical seiche model would agree with the data even if our hypothesis is correct. A better way to confirm (or negate) the hypothesis would be to analyze data from a number of simultaneously running pressure sensors, velocity profilers 

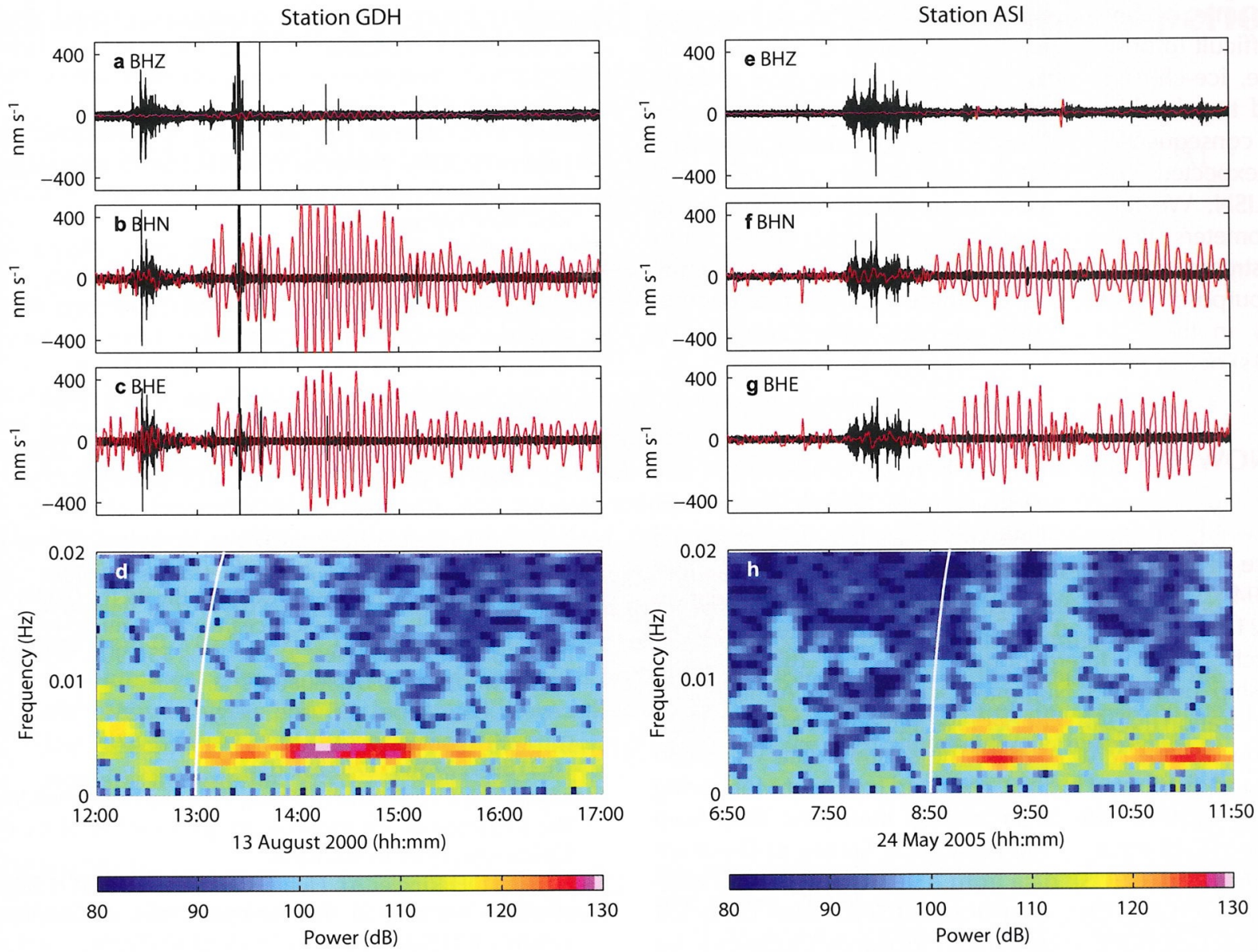

Fig. 4. Seismic data from calving icebergs. (a-c) Data from the vertical, north, and east channels of station GDH from 13 August 2000. The data were filtered with a $2-5 \mathrm{~Hz}$ bandpass filter (black) and a 120-1200 s bandpass filter (red); the plots therefore show the velocity within each bandpass. As with Figure 3, we emphasize that these signals were not corrected for frequency response. The 2-5 $\mathrm{Hz}$ energy is characteristic of all calving events, whereas the 120-1200 s energy appears to represent ground tilt caused by calving-generated ocean waves. (d) Spectrogram of the east channel of station GDH. (e-g) Same as (a-c) for a calving event recorded at station ASI on 24 May 2005. (h) Spectrogram of the east channel of station ASI. The white curves indicate the expected frequency dispersion for a tsunami that originated from the glacier terminus. Note the lack of dispersion in the low-frequency signals.

and seismometers; unfortunately the data needed for such an exercise are not currently available. Although we are unable to negate other possible hypotheses, such as nonlinear wave interactions, our hypothesis appears to be the simplest that is consistent with the data on hand.

\section{CONCLUSIONS}

Calving events at Jakobshavn Isbræ generate long-period ocean waves that can be recorded by coastal broadband seismometers located (at least) $150 \mathrm{~km}$ from the terminus. The waves are not dispersive, have distinct spectral peaks, persist for several hours and have similar frequency content from one event to the next. We suggest that these calvinggenerated waves are seiches, or basin eigenmodes, of Ilulissat Icefjord and Disko Bay. Thus the calving events affect $>1000 \mathrm{~km}^{3}$ of water, which is a testament to the large amount of energy released by icebergs that capsize as they calve into the ocean (see also MacAyeal and others, 2011). Preliminary analysis of data from GLISN stations KULLO and NUUG, which are located in West Greenland near other calving termini, suggests that these waves are not unique to Jakobshavn Isbræ.

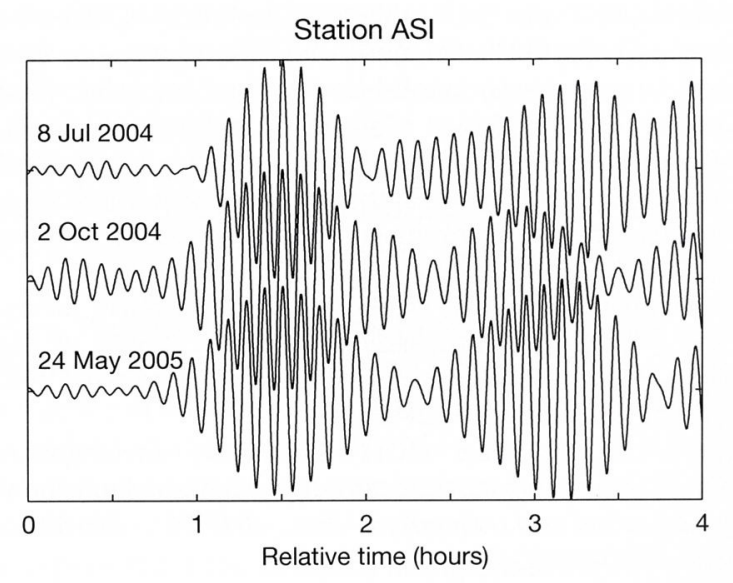

Fig. 5. Long-period, horizontal (east channel) ground tilt recorded at station ASI following calving events. The seismograms were filtered with a $340-440 \mathrm{~s}$ bandpass filter in order to isolate the strong spectral peaks shown in Figure $4 \mathrm{~h}$. The time axes have been shifted to illustrate the similarity of the signals. For each of the waveforms, the calving event began around 0.25 hours (determined by inspecting the associated $2-5 \mathrm{~Hz}$ energy that is indicative of calving events). 
Dynamic, oceanographic consequences of calving events are difficult to observe due to the hazards of instrumenting remote, ice-choked fjords. Our observations have demonstrated that land-based seismometers can record some of these consequences, i.e. ocean waves, thereby providing an unexpected application of polar seismic networks such as GLISN. We therefore advocate coastal deployment of seismometers in polar regions, preferably along fjords downstream of major calving fronts, as they can serve the dual purpose of recording calving events (with maximum energy in the $2-5 \mathrm{~Hz}$ band) and associated long-period (>100s) ocean waves.

\section{ACKNOWLEDGEMENTS}

Funding for this project was provided by NASA's Cryospheric Sciences Program (NNG06GB49G), the US National Science Foundation (ARC0531075, ARC0909552 and ANT0944193), the Swiss National Science Foundation (200021-113503/1) and a Cooperative Institute for Arctic Research (CIFAR) International Polar Year (IPY) student fellowship under US National Oceanic and Atmospheric Administration (NOAA) cooperative agreement NA17RJ1224 with the University of Alaska. The seismic data were collected and distributed by the Greenland Ice Sheet Monitoring Network (GLISN) federation and its members: data from $\mathrm{GDH}$ were collected by the Geological Survey of Denmark and Greenland (GEUS); data from ASI, ILU and SUMG were collected by GEOFON; data from SFJ/SFJD were collected by GEUS, GEOFON, Incorporated Research Institutions for Seismology (IRIS) and the Comprehensive Test-Ban Treaty Organization (CTBTO); and data from ILULI were collected by ETH. We thank J. Brown and D. Podrasky for assistance with fieldwork and D.R. MacAyeal and E.A. Okal for discussions that led to and improved the manuscript. The manuscript benefited from the comments of O. Sergienko, an anonymous reviewer and editor P. Christoffersen.

\section{REFERENCES}

Amundson JM, Truffer M, Lüthi MP, Fahnestock $M$, West $M$ and Motyka RJ (2008) Glacier, fjord, and seismic response to recent large calving events, Jakobshavn Isbræ, Greenland. Geophys. Res. Lett., 35(22), L22501 (doi: 10.1029/2008GL035281)

Amundson JM, Fahnestock M, Truffer M, Brown J, Lüthi MP and Motyka RJ (2010) Ice mélange dynamics and implications for terminus stability, Jakobshavn Isbræ, Greenland. J. Geophys. Res., 115(F1), F01005 (doi: 10.1029/2009JF001405)

Birnie RV and Williams JM (1985) Monitoring iceberg production using LANDSAT. In Proceedings of the University of Dundee Summer School. European Space Agency, Noordwijk, 165-167 (ESA Special Publication SP-216)

Burton J and 9 others (2012) Laboratory investigations of iceberg capsize dynamics, turbulent energy dissipation and tsunamigenesis. J. Geophys. Res., 117(F1), F01007 (doi: 10.1029/2011JF002055)

Csatho B, Schenk T, Van der Veen CJ and Krabill WB (2008) Intermittent thinning of Jakobshavn Isbræ, West Greenland, since the Little Ice Age. J. Glaciol., 53(184), 131-144 (doi: 10.3189/002214308784409035)
Epprecht W (1987) A major calving event of Jakobshavn Isbræ, West Greenland, on 9 August 1982. J. Glaciol., 33(114), 169-172

Gill AE (1982) Atmosphere-ocean dynamics. Academic Press, San Diego, CA

Holland DM, Thomas RH, de Young B, Ribergaard $\mathrm{MH}$ and Lyberth B (2008) Acceleration of Jakobshavn Isbræ triggered by warm subsurface ocean waters. Nature Geosci., 1(10), 659-664 (doi: 10.1038/ngeo316)

Hutter K, Wang Y and Chubarenko IP (2011) Physics of lakes. Volume 2: Lakes as oscillators. Springer, Heidelberg

Joughin I, Abdalati W and Fahnestock MA (2004) Large fluctuations in speed on Greenland's Jakobshavn Isbræ glacier. Nature, 432(7017), 608-610 (doi: 10.1038/nature03130)

La Rocca M, Galluzzo D, Saccorotti G, Tinti S, Cimini GB and Del Pezzo E (2004) Seismic signals associated with landslides and with a tsunami at Stromboli volcano, Italy. Bull. Seismol. Soc. Am., 94(5), 1850-1867 (doi: 10.1785/012003238)

Luckman A and Murray T (2005) Seasonal variation in velocity before retreat of Jacobshavn Isbræ, Greenland. Geophys. Res. Lett., 32(8), L08501 (doi: 10.1029/2005GL022519)

MacAyeal DR, Okal EA, Aster RC and Bassis JN (2009) Seismic observations of glaciogenic ocean waves (micro-tsunamis) on icebergs and ice shelves. J. Glaciol., 55(190), 193-206 (doi: 10.3189/002214309788608679)

MacAyeal DR, Abbot DS and Sergienko OV (2011) Icebergcapsize tsunamigenesis. Ann. Glaciol., 52(58), 51-56 (doi: 10.3189/172756411797252103)

MacAyeal DR, Freed-Brown J, Zhang WW and Amundson JM (2012) The influence of ice melange on fjord seiches. Ann. Glaciol., 53(60) (see paper in this issue)

McNamara DE, Ringler AT, Hutt CR and Gee LS (2011) Seismically observed seiching in the Panama Canal. J. Geophys. Res., 116(B4), B04312 (doi: 10.1029/2010JB007930)

Munk WH, Miller GR, Snodgrass FE and Barber NF (1963) Directional recording of swell from distant storms. Philos. Trans. R. Soc. London, Ser. A, 255(1062), 505-584

Nettles $M$ and 12 others (2008) Step-wise changes in glacier flow speed coincide with calving and glacial earthquakes at Helheim Glacier, Greenland. Geophys. Res. Lett., 35(24), L24503 (doi: 10.1029/2008GL036127)

O'Neel S, Larsen CF, Rupert N and Hansen R (2010) Iceberg calving as a primary source of regional-scale glacier-generated seismicity in the St Elias Mountains, Alaska. J. Geophys. Res., 115(F4), F04034 (doi: 10.1029/2009JF001598)

Okal EA (2007) Seismic records of the 2004 Sumatra and other tsunamis: a quantitative study. Pure Appl. Geophys., 164(2-3), 325-353 (doi: 10.1007/s00024-006-0181-4)

Rabinovich AB (2009) Seiches and harbor oscillations. In Kim YC ed. Handbook of coastal and ocean engineering. World Scientific, Singapore, 193-236

Rignot E and Kanagaratnam P (2006) Changes in the velocity structure of the Greenland Ice Sheet. Science, 311(5673), 986-990 (doi: 10.1126/science.1121381)

Stove GC and 8 others (1983) The use of Landsat data to monitor iceberg production: results from the AGRISPINE experiment for the Jakobshavns Isbræ. Macaulay Institute for Soil Research, Aberdeen; National Remote Sensing Centre, Royal Aircraft Establishment, Farnborough

Thomas RH, Abdalati W, Frederick E, Krabill WB, Manizade S and Steffen K (2003) Investigation of surface melting and dynamic thinning on Jakobshavn Isbræ, Greenland. J. Glaciol., 49(165), 231-239 (doi: 10.3189/172756503781830764)

Yuan X, Kind R and Pedersen HA (2005) Seismic monitoring of the Indian Ocean tsunami. Geophys. Res. Lett., 32(15), L15308 (doi: 10.1029/2005GL023464) 